\title{
Kamila Słupska
}

Zakład Pedagogiki Społecznej

Wydział Studiów Edukacyjnych

Uniwersytet im. Adama Mickiewicza w Poznaniu

e-mail: skami@amu.edu.pl

\section{Ważna czy nieistotna? \\ Książka w codzienności współczesnej młodzieży (komunikat z badań)}

\author{
DOI: http://dx.doi.org/10.18778/0860-7435.29.06
}

\begin{abstract}
Abstrakt: Wyniki ogólnopolskich badań poziomu czytelnictwa nie napawają optymizmem. Okazuje się, że czytanie książek nie jest powszechną normą kulturową. W wystąpieniu podjęta zostanie próba pokazania, jaką rolę odgrywa książka w życiu współczesnego młodego pokolenia (czy jest ona postrzegana w kategoriach niezbędnego atrybutu codzienności, czy też tolerowanego, aczkolwiek niekoniecznie pożądanego jej elementu). Ilustracją czynionych analiz będą wyniki badań empirycznych prowadzonych wśród młodzieży w wieku 18-20 lat, a zatem kończącej kolejny etap kształcenia i znajdującej się w takim okresie, kiedy to ulegają (uległy) wyraźnej modyfikacji zainteresowania lekturowe. Akcentując pedagogiczną perspektywę (i związane z nią procesy socjalizacyjne), podkreślona zostanie również kwestia środowiska życia młodych ludzi, czyli osób z bliskiego otoczenia, mających wpływ, w ciągu całej ich dotychczasowej biografii, na aktywność czytelniczą.
\end{abstract}

Słowa kluczowe: młodzież, aktywność czytelnicza, motywy czytania 


\section{Wprowadzenie w problematykę}

- Czytelnictwo rozumiane jako ważna praktyka społeczna umożliwiająca sprawne komunikowanie w skali ponadlokalnej liczy sobie wiele wieków i w tym sensie można mówić, że trwa. Jednocześnie jednak uległo ono w owym czasie rozmaitym przekształceniom, tak więc jego dzisiejszy obraz różni się znacznie od tego sprzed kilku stuleci, a nawet sprzed kilkudziesięciu czy kilkunastu laty (Kostecki, 2017, s. 93).

Podobnie na przestrzeni wieków ulegało modyfikacji nastawienie do książki i lektury jako praktyki społecznej (od jej postrzegania w kategoriach typowo sakralnych do traktowania jako źródła zarówno wiedzy, jak i rozrywki) (Tamże, s. 95). Niewątpliwie, książka jest ciagle obecna w przestrzeni społecznej. Trudno wyobrazić sobie jej brak, gdyż funkcje, jakie pełni i cele, którym służy, są nie do przecenienia. Jednocześnie aktywność czytelnicza społeczeństwa już taka oczywista nie jest i budzi niepokój, biorąc pod uwagę wyniki badań. Zgodnie z raportem Biblioteki Narodowej, w 2017 r. 38\% respondentów zadeklarowało kontakt z książką (zapoznanie się z nią w całości lub we fragmentach), w tym 9\% przeczytało co najmniej 7 książek. Od kilku lat poziom czytelnictwa ustabilizował się (po widocznym jego spadku w 2008 roku). Młodzi, czyli uczniowie i studenci, w związku z uczestnictwem w procesach edukacyjnych, stanowią kategorię, dla której książka raczej jest obecna w codzienności, choć nie można mówić o jednorodnym obrazie w tym zakresie. I pomimo, iż są oni grupa, której aktywność czytelnicza jest wyższa niż innych, to jednak problem spadku poziomu czytelnictwa jest faktem: 35\% młodych ludzi w wieku 15-19 lat deklaruje, iż nie przeczytało ani jednej książki w ciągu ostatniego roku (w 2000 r. było to $16 \%$, w $2010-25 \%$ ) (Koryś i in., 2018). Można zaobserwować również prawidłowość związana z „gubieniem się" czytelnika po drodze, tzn. kurczeniem się wraz z wiekiem liczby osób deklarujących czytanie. Badania zrealizowane przez Instytut Badań Edukacyjnych w 2013 r. ujawniły, iż żadnej książki (związanej czy z obowiązkiem szkolnym, czy też poza nim) nie przeczytało 5\% uczniów szóstych klas szkół podstawowych i 14\% uczniów trzecich klas gimnazjów (Zasacka, 2014, s. 55). Ogólnopolskie badanie czytelnictwa młodzieży (trzecich klas szkół gimnazjalnych, IV edycja), zrealizowane przez Bibliotekę Narodową w 2017 r. wykazało wzrost (choć nieznaczny) czytających w czasie wolnym (z 62\% do 65\%), a to za sprawą dziewcząt, gdzie taką deklarację złożyło 82\% z nich (wśród chłopców ta praktyka tak popularna nie jest - 49\%) (W zrost crytelnictwa nastoletnich driewcrat, 2018).

Pytanie, jakie miejsce zajmuje książka w codzienności współczesnych młodych ludzi wydaje się zatem cały czas aktualne i niezwykle istotne. I właśnie temu zagadnieniu poświęcony jest niniejszy artykuł, w którym autorka 
przywołuje wyniki przeprowadzonych przez siebie badań, traktując je nie w kategoriach rozstrzygających, ale jako ilustrację czynionych rozważań i przyczynek do kolejnych dociekań empirycznych. Przyjmując głównie pedagogiczny punkt widzenia, pragnie zaakcentować ważkość problematyki, dokonując rozpoznania wycinka rzeczywistości czytelniczej młodzieży, znajdujacej się u progu dorosłości, kiedy to m.in. ulegają modyfikacji zainteresowania lekturowe. Należy pamiętać, iż „w ciagu całego życia (...) jednostka zdobywa wiedzę i różne umiejętności, czyli poszerza swoje zasoby, modyfikuje strategie radzenia sobie w różnych sytuacjach, uczy się na swoich błędach, wyciaga wnioski z sytuacji, w których odniosła sukces bądź doznała porażki”, kształtując „coraz większą świadomość bycia odrębna (...) i poczucia tożsamości” (Brzezińska, 2017, s. 390). Kwestia udziału książki w tym „gromadzeniu doświadczeń” i „rozpoznawaniu rzeczywistości” oraz jej miejsca w tych procesach wydaje się oczywista, a jednocześnie, biorąc pod uwagę zatrważająco niskie wskaźniki, świadczące często o niezainteresowaniu, pomijaniu, niedocenianiu jej roli, wymaga akcentowania, zarówno w wymiarze indywidualnym, jak i społecznym; teoretycznym, jak i praktycznym.

\section{T Aktywność czytelnicza młodych}

L Badania przeprowadzono wśród młodzieży województwa wielkopolskiego, w marcu 2018 roku. Grupa badawcza liczyła 80 osób. Byli to uczniowie szkół ponadgimnazjalnych (liceum i technikum), w wieku od 18 do 21 lat (tabela 1). W tej grupie 62,5\% stanowily dziewczęta, natomiast $37,5 \%$ chłopcy (tabela 2); większość to osoby zamieszkujące miasto (tabela 3). Posłużono się metodą sondażu diagnostycznego, wykorzystując anonimowa ankietę, która składała się z 12 pytań: zamkniętych, półotwartych i otwartych ${ }^{1}$. Istotną kwestią diagnostyczno-poznawczą stało się poszukiwanie odpowiedzi na pytania dotyczące znaczenia książki w życiu młodych ludzi, czyli ich aktywności czytelniczej, w tym m.in. intensywności praktyk lekturowych, nastawienia do czytania, oceny zarówno osobistego, jak i odnoszącego się do ich własnego pokolenia zaangażowania w tym zakresie, także preferencji lekturowych oraz udziału osób najbliższych w procesie socjalizacji czytelniczej.

\footnotetext{
${ }^{1} \mathrm{Z}$ racji zainteresowań naukowych autorki, podobne przedsięwzięcie badawcze zrealizowała ona już wcześniej (w roku akademickim 2012/2013), biorąc pod uwagę opinie studentów pedagogiki (111 osób w wieku 20-24 lata i więcej) (Słupska, 2016a), wprowadzając pewne klasyfikacje, do których odwołania znajdą się również w niniejszym artykule, stanowiąc - w wybranym zakresie - materiał porównawczy.
} 
Tab. 1. Podział ankietowanych ze względu na wiek $(\mathrm{N}=80)$

\begin{tabular}{|l|c|c|}
\hline \multicolumn{1}{|c|}{ Wiek } & Liczba & $\mathbf{\%}$ \\
\hline 18 lat & 8 & 10,0 \\
\hline 19 lat & 50 & 62,5 \\
\hline 20 lat & 16 & 20,0 \\
\hline 21 lat & 6 & 7,5 \\
\hline \multicolumn{3}{|c}{} \\
Źródło: oprac. własne.
\end{tabular}

Tab. 2. Podział ankietowanych ze względu na płeć $(\mathrm{N}=80)$

\begin{tabular}{|l|c|c|}
\hline \multicolumn{1}{|c|}{ Płeć } & Liczba & \% \\
\hline Kobieta & 50 & 62,5 \\
\hline Mężczyzna & 30 & 37,5 \\
\hline
\end{tabular}

Źródło: oprac. własne.

Tab. 3. Podział ankietowanych

ze względu na miejsce zamieszkania $(\mathrm{N}=80)$

\begin{tabular}{|l|c|c|}
\hline \multicolumn{1}{|c|}{ Płeć } & Liczba & \% \\
\hline Miasto & 62 & 77,5 \\
\hline Wieś & 18 & 22,5 \\
\hline
\end{tabular}

Źródło: oprac. własne.

Dla większości badanej młodzieży czytanie jest przyjemnością - pod warunkiem, iż sama dokonuje swobodnego wyboru (72,5\%). Odpowiedzi biegunowo skrajne, czyli odnoszące się do - z jednej strony zamiłowania do książek (uwielbiam czytać „zawsze”, „wszędzie”, „,wszystko”), z drugiej zaś - do jawnie okazywanej niechęci (konieczność, przymus) wskazało tylu samo ankietowanych (po 13,75\%). Przeważa zatem kategoria „czytelników warunkowych” (dwie pozostałe, wprowadzone przez autorkę, to: „czytelnicy bezwarunkowi” i „czytelnicy nieczytający”). Biorąc pod uwagę podział ze względu na płeć, to zarówno wśród dziewcząt, jak i chłopców najwięcej jest czytających z przyjemnością, jednak tylko to niezwiązane z przymusem, ale już wśród deklarujących czytanie tylko i wyłącznie z konieczności dużo większa grupę stanowią ci drudzy, gdzie prawie co trzeci wymienił taką odpowiedź, a tylko jeden chłopiec wskazał, iż uwielbia czytać i sprawia mu to przyjemność zawsze (wśród dziewcząt ta grupa była zdecydowanie większa - 1/5 z nich wyraziła taką opinię) (tabela 4). 
Tab. 4. Deklarowane przez respondentów nastawienie do czytania $(\mathrm{N}=80)$

\begin{tabular}{|l|c|c|c|c|c|c|}
\hline \multirow{2}{*}{ Czzytanie jest dla mnie } & \multicolumn{2}{|c|}{ Wszyscy } & \multicolumn{3}{c|}{ Wskazania ze względu na płeć } \\
\cline { 2 - 7 } & & \multicolumn{2}{|c|}{ K } & \multicolumn{2}{c|}{ M } \\
\cline { 2 - 7 } & Liczba & $\mathbf{\%}$ & Liczba & $\mathbf{\%}$ & Liczba & $\%$ \\
\hline $\begin{array}{l}\text { Przyjemnościa, ale tylko to } \\
\text { niezwiazzane z przymusem }\end{array}$ & 58 & 72,50 & 38 & 76,00 & 20 & 66,67 \\
\hline Przyjemnością zawsze & 11 & 13,75 & 10 & 20,00 & 1 & 3,33 \\
\hline Koniecznością & 11 & 13,75 & 2 & 4,00 & 9 & 30,00 \\
\hline
\end{tabular}

Źródło: oprac. własne.

Jeśli chodzi o kategorię dominująca, to wyniki są zbieżne $z$ tymi uzyskanymi w badaniu realizowanym wśród studentów, gdzie jednak grupa miłośników czytania była zdecydowanie większa niż grupa czytelniczych sceptyków (tabela 5). Wynikać to może z faktu dokonania kolejnego kroku w karierze edukacyjnej, a mianowicie świadomie podjętej decyzji o kontynuacji nauki na studiach wyższych, sprofilowanych humanistycznie, które związane są m.in. $\mathrm{z}$ nastawieniem na stały kontakt z książką (w obszarze zarówno lektury obowiązkowej, jak i uzupełniającej).

Tab. 5. Wyróżnione typy czytelników ( $\mathrm{N}=80 ; \mathrm{N}=111)$

\begin{tabular}{|c|c|c|c|c|}
\hline \multirow[t]{2}{*}{ Typy czytelników } & \multicolumn{2}{|c|}{$\begin{array}{c}\text { Młodzież szkół } \\
\text { ponadgimnazjalnych } \\
(2018) \\
\mathrm{N}=80\end{array}$} & \multicolumn{2}{|c|}{$\begin{array}{c}\text { Młodzież studiująca } \\
(2012-2013) \\
\text { N=111 }\end{array}$} \\
\hline & Liczba & $\%$ & Liczba & $\%$ \\
\hline Czytelnicy warunkowi & 58 & 72,50 & 84 & 75,68 \\
\hline Czytelnicy bezwarunkowi & 11 & 13,75 & 23 & 20,72 \\
\hline Czytelnicy nieczytający & 11 & 13,75 & 4 & 3,60 \\
\hline
\end{tabular}

Źródło: oprac. własne.

Biorąc pod uwagę stopień aktywności czytelniczej, podstawową kwestią okazuje się częstotliwość i intensywność czytania. W przypadku młodzieży należy wziąć pod uwagę dwie sytuacje czytelnicze: swobodny wybór (czytanie w czasie wolnym) oraz czytanie obowiązkowe (szkolne). Najwięcej młodzieży odpowiedziało, iż w czasie wolnym czyta kilka razy w roku $(27,5 \%)$ oraz co najmniej raz na miesiąc $(26,25 \%), 4$ respondentów natomiast zadeklarowało, iż nie czyni tego nigdy. Wśród dziewcząt więcej jest czytających codziennie lub prawie codziennie (14\% do $10 \%$ chłopców) oraz co najmniej raz w tygodniu (18\% do 10\% chłopców), natomiast wśród chłopców - rzadziej niż raz w roku ( $20 \%$ do $10 \%$ dziewczat) i nigdy (10\% do $2 \%$ dziewcząt) (tabela 6.) 
Tab. 6. Częstotliwość czytania w opinii respondentów (N=80)

\begin{tabular}{|l|c|c|c|c|c|c|}
\hline \multirow{2}{*}{ Częstotliwość czytania } & \multicolumn{2}{|c|}{ Wszyscy } & \multicolumn{3}{c|}{ Wskazania ze względu na płeć } \\
\cline { 4 - 7 } & & \multicolumn{2}{|c|}{ K } & \multicolumn{2}{c|}{ M } \\
\cline { 2 - 7 } & Liczba & $\mathbf{0}$ & Liczba & $\mathbf{\%}$ & Liczba & $\%$ \\
\hline $\begin{array}{l}\text { Codziennie lub prawie } \\
\text { codziennie }\end{array}$ & 10 & 12,50 & 7 & 14,00 & 3 & 10,00 \\
\hline Co najmniej raz w tygodniu & 12 & 15,00 & 9 & 18,00 & 3 & 10,00 \\
\hline Co najmniej raz na miesiąc & 21 & 26,25 & 14 & 28,00 & 7 & 23,33 \\
\hline Kilka razy w roku & 22 & 27,50 & 14 & 28,00 & 8 & 26,67 \\
\hline Rzadziej niż raz w roku & 11 & 13,75 & 5 & 10,00 & 6 & 20,00 \\
\hline Nigdy & 4 & 5,00 & 1 & 2,00 & 3 & 10,00 \\
\hline
\end{tabular}

Źródło: oprac. własne.

Dominuje zatem grupa zaangażowanych w stopniu średnim $(53,75 \%$; czytający kilka razy w roku oraz co najmniej raz na miesiąc), w dalszej kolejności - mocno zaangażowanych $(27,5 \%$; czytający co najmniej raz w tygodniu oraz codziennie lub prawie codziennie) oraz raczej niezainteresowanych (18,75\%; czytający rzadziej niż raz w roku oraz nigdy). Wśród osób, które stwierdzily, iż czytanie jest dla nich koniecznością: 1 - czyta kilka razy w roku, 6 - rzadziej niż raz w roku, a 4 - nigdy.

Respondenci zostali zapytani również o przeciętną liczbę czytanych książek (poza lekturami szkolnymi) (tabela 7). Dwie odpowiedzi były wybierane najczęściej: średnio 1 książkę na miesiąc $(30 \%)$ oraz średnio 1-2 książki na pół roku (28,75\%), a zatem dominująca grupa okazują się - nazwani umownie - „czytelnicy umiarkowani”. Jeśli chodzi o wskazanie kilku książek w miesiącu przodują dziewczęta (18\% do 3,33\% chłopców), zasilając tym samym szeregi „Czytelników intensywnych”. Chłopcy wyraźnie plasują się na przeciwległym biegunie - „czytelników potencjalnych”, czyli tych czytających najmniej albo w ogóle (aż 46,66\%! do 18\% dziewcząt).

Tab. 7. Intensywność czytania w czasie wolnym w opinii respondentów $(\mathrm{N}=80)$

\begin{tabular}{|c|c|c|c|c|c|c|}
\hline \multirow{3}{*}{$\begin{array}{c}\text { Liczba książek } \\
\text { czytanych } \\
\text { w czasie wolnym }\end{array}$} & \multirow{2}{*}{\multicolumn{2}{|c|}{ Wszyscy }} & \multicolumn{4}{|c|}{ Wskazania ze względu na płeć } \\
\hline & & & \multicolumn{2}{|c|}{$\mathbf{K}$} & \multicolumn{2}{|c|}{$\mathbf{M}$} \\
\hline & Liczba & $\%$ & Liczba & $\%$ & Liczba & $\%$ \\
\hline Kilka w miesiącu & 10 & 12,50 & 9 & 18,00 & 1 & 3,33 \\
\hline Średnio 1 książkę na miesiąc & 24 & 30,00 & 16 & 32,00 & 8 & 26,67 \\
\hline $\begin{array}{l}\text { Średnio 1-2 książki na pół } \\
\text { roku }\end{array}$ & 23 & 28,75 & 16 & 32,00 & 7 & 23,33 \\
\hline Mniej & 19 & 23,75 & 9 & 18,00 & 10 & 33,33 \\
\hline Nie czytam & 4 & 5,00 & 0 & - & 4 & 13,33 \\
\hline
\end{tabular}

Źródło: oprac. własne. 
Jeśli chodzi o czytanie lektur, uzyskane odpowiedzi niestety nie napawaja optymizmem. Prawie $1 / 3$ respondentów przyznaje, iż czyta jedynie streszczenia (co koresponduje z wynikami innych badań przeprowadzonych wśród uczniów trzecich klas liceów oraz nauczycieli polonistów, którzy przyznali, iż zamienniki lekturowe, czyli bryki i opracowania to bardzo często stosowane środki zastępcze, a dzięki informacjom pochodzącym właśnie z tego źródła 47\% młodzieży deklaruje znajomość lektur; Mazur, 2012, s. 194), niewiele mniej (30\%), iż zapoznaje się tylko z fragmentami omawianych na lekcjach książek (jeśli chodzi o wybór rozwiązań nastawionych bardziej na unikanie niż angażowanie przoduja chłopcy) (tabela 8.). Jako przyczyny takiego stanu rzeczy respondenci najczęściej podaja argumenty typu: „są nudne”, „nie interesują mnie”, „nie mam czasu”, ,ich język mi nie odpowiada”. Wśród osób, które deklaruja czytanie lektur (wszystkich lub niektórych), ale w całości (30 osób; $37,5 \%$ ) prym wiodą dziewczęta (24 z nich, chłopców - jedynie 6). Argumenty tych respondentów można podzielić na dwie główne grupy: - „czytanie z przekonania”, czyli lektura ma dla nich wartość sama w sobie (,sa ciekawe”, „warto poznać nowe utwory”) oraz - „czytanie z obowiązku”, czyli instrumentalne traktowanie lektury („muszę”, „to niezbędne do zdania matury”, „chcę mieć dobre oceny”). Biorąc pod uwagę odwołania do wyróżnionych (ze względu na deklarowane nastawienie do czytania i intensywność wyrażajacą się średnią liczbą czytanych pozycji) - przywołanych wyżej - typów czytelników, to wśród respondentów, zarówno chętnych odbiorców lektur, jak i sceptyków oraz osób wyraźnie ich unikających dominuja „czytelnicy warunkowi”, czyli ci, dla których czytanie - ale tylko to niezwiązane z jakimkolwiek przymusem - jest przyjemnością oraz „czytelnicy umiarkowani”, czytający (poza lekturami) średnio kilka książek w roku. Więcej „,czytelników bezwarunkowych” i „czytelników intensywnych” zaznacza także swoja aktywność w kontekście zapoznawania się z utworami obowiązującymi w ramach kanonu szkolnego. Natomiast tzw. „czytelnicy nieczytający”, dla których kontakt z książką jest (ewentualnie) podejmowany z konieczności oraz „czytelnicy potencjalni”, deklarujący czytanie mniej niż 2 książek w ciagu roku lub nieczytanie w ogóle, to albo okazjonalni użytkownicy (zapoznawanie się fragmentaryczne), albo negujący sens tego obowiązku i bazujący jedynie na opracowaniach. Można zatem powiedzieć, iż są oni „konsekwentni” w swoim podejściu, deklarując niechęć zarówno do lektur szkolnych, jak i pozaobowiązkowego czytania. Sytuacja jest nieco inna w odniesieniu do dwóch pierwszych kategorii. Nawet wśród „czytelników bezwarunkowych”, akcentujących swoje bardzo pozytywne nastawienie do czytania zawsze, sa tacy, którzy jednak „rezygnują” (częściowo lub całkowicie) z lektury obowiązującej w ramach programu szkolnego $(36,36 \%)$ i wśród „,czytelników intensywnych”, czyli naj- 
bardziej aktywnych w obszarze czytania spontanicznego także znajdują się niepraktykujący czytanie lektur lub czyniący to jedynie fragmentarycznie ${ }^{2}$.

Tab. 8. Czytanie lektur przez respondentów $(\mathrm{N}=80)$

\begin{tabular}{|c|c|c|c|c|c|c|}
\hline \multirow{3}{*}{ Czytanie lektur } & \multirow{2}{*}{\multicolumn{2}{|c|}{ Wszyscy }} & \multicolumn{4}{|c|}{ Wskazania ze względu na płeć } \\
\hline & & & \multicolumn{2}{|c|}{$\mathbf{K}$} & \multicolumn{2}{|c|}{$\mathbf{M}$} \\
\hline & Liczba & $\%$ & Liczba & $\%$ & Liczba & $\%$ \\
\hline Zawsze lub prawie zawsze w całości & 13 & 16,25 & \multirow[t]{8}{*}{10} & \multirow[t]{8}{*}{20,00} & \multirow[t]{8}{*}{3} & \multirow[t]{8}{*}{10,00} \\
\hline \multicolumn{3}{|l|}{ w tym: } & & & & \\
\hline Czytelnicy warunkowi & 10 & 76,29 & & & & \\
\hline Czytelnicy bezwarunkowi & 3 & 23,08 & & & & \\
\hline Czytelnicy nieczytający & 0 & - & & & & \\
\hline Czytelnicy intensywni & 2 & 15,38 & & & & \\
\hline Czytelnicy umiarkowani & 9 & 69,23 & & & & \\
\hline Czytelnicy potencjalni & 2 & 15,38 & & & & \\
\hline W całości, ale tylko wybrane & 17 & 21,25 & \multirow[t]{8}{*}{14} & \multirow[t]{8}{*}{28,00} & \multirow[t]{8}{*}{3} & \multirow[t]{8}{*}{10,00} \\
\hline \multicolumn{3}{|l|}{ w tym: } & & & & \\
\hline Czytelnicy warunkowi & 13 & 76,47 & & & & \\
\hline Czytelnicy bezwarunkowi & 4 & 23,53 & & & & \\
\hline Czytelnicy nieczytający & 0 & - & & & & \\
\hline Czytelnicy intensywni & 4 & 23,53 & & & & \\
\hline Czytelnicy umiarkowani & 11 & 64,71 & & & & \\
\hline Czytelnicy potencjalni & 2 & 11,76 & & & & \\
\hline Czytanie jedynie fragmentów & 24 & 30,00 & \multirow[t]{8}{*}{12} & \multirow[t]{8}{*}{24,00} & \multirow[t]{8}{*}{12} & \multirow[t]{8}{*}{40,00} \\
\hline \multicolumn{3}{|l|}{ w tym: } & & & & \\
\hline Czytelnicy warunkowi & 19 & 79,17 & & & & \\
\hline Czytelnicy bezwarunkowi & 2 & 8,33 & & & & \\
\hline Czytelnicy nieczytający & 3 & 12,50 & & & & \\
\hline Czytelnicy intensywni & 1 & 4,17 & & & & \\
\hline Czytelnicy umiarkowani & 18 & 75,00 & & & & \\
\hline Czytelnicy potencjalni & 5 & 20,83 & & & & \\
\hline $\begin{array}{l}\text { Zapoznawanie się wyłącznie ze } \\
\text { streszczeniami }\end{array}$ & 26 & 32,50 & \multirow[t]{8}{*}{14} & \multirow[t]{8}{*}{28,00} & \multirow[t]{8}{*}{12} & \multirow[t]{8}{*}{40,00} \\
\hline \multicolumn{3}{|l|}{ w tym: } & & & & \\
\hline Czytelnicy warunkowi & 16 & 61,54 & & & & \\
\hline Czytelnicy bezwarunkowi & 2 & 7,69 & & & & \\
\hline Czytelnicy nieczytający & 8 & 30,77 & & & & \\
\hline Czytelnicy intensywni & 3 & 11,54 & & & & \\
\hline Czytelnicy umiarkowani & 9 & 34,61 & & & & \\
\hline Czytelnicy potencjalni & 14 & 53,85 & & & & \\
\hline
\end{tabular}

Źródło: oprac. własne.

2 „Czytelnicy bezwarunkowi” w większości czytają lektury $(63,63 \%)$, podobnie - „,czytelnicy intensywni” (60\%), natomiast „czytelnicy warunkowi” - raczej sceptycznie do nich podchodzą (deklarując albo czytanie tylko fragmentów, albo zapoznawanie się ze streszczeniami) - 60,35\%, i znów podobnie - „czytelnicy umiarkowani” (57,45\%). 
Bez wątpienia najskuteczniejszą zachętą do kontaktu z książką jest rozbudzenie przyjemności czytania (co jest związane z zaangażowaniem w ten proces, o którym decyduje motywacja, głównie motywacja wewnętrzna i skorelowane z nią przekonanie o znaczeniu książek w codzienności, która jednak może ulegać zintegrowaniu z motywacją zewnętrzną - kojarzoną bezpośrednio z możliwością uzyskania gratyfikacji < dobrą oceną, pochwałą $>$ ). Jest to ważna konkluzja dla praktyki szkolnej (Zasacka, 2013, s. 96-97). A jednocześnie, biorąc pod uwagę sceptycyzm badanej młodzieży do dzieł, z którymi jest zobligowana się zapoznać, trzeba zadać pytanie: co w takiej sytuacji robić? Jakie antidotum zastosować na tę niechęć? Niewatpliwie, udział szkoły, począwszy od aktywności podejmowanych już w klasach najmłodszych, jest nie do przecenienia. Anna Janus-Sitarz podkreśla istotność czterech wyzwań stojących przed nauczycielem polonista, który powinien:

rozpoznać potrzeby i bariery czytelnicze swoich podopiecznych; pobudzić apetyt na czytanie, bowiem nikt nie rodzi się czytelnikiem, a środowisko rodzinne niekoniecznie sprzyja wykształceniu nawyków czytelniczych; indywidualizować dobór lektur; poszukiwać książek wartościowych, a jednocześnie dających szanse na zachęcenie młodych ludzi do czytania poza przymusem lekturowym (2016, s. 176).

Biorąc pod uwage preferowane typy literatury, największą popularnościa wśród respondentów cieszy się literatura kryminalna/sensacyjna, następnie: obyczajowa, przygodowa/podróżnicza i fantastyka. Trochę inaczej te upodobania rozkładają się, jeśli chodzi o płeć. Wśród dziewcząt dominuje ex aequo literatura kryminalna/sensacyjna i obyczajowa, wśród chłopców natomiast: fantastyka oraz (równa liczba wskazań) kryminalna/sensacyjna i przygodowa/podróżnicza. Dziewczęta częściej też wskazują literaturę faktu/biografie i tylko one zwróciły uwagę na poezję (tabela 9.).

Tab. 9. Preferencje czytelnicze respondentów ( $\mathrm{N}=74)$

\begin{tabular}{|c|c|c|c|c|c|c|}
\hline \multirow{3}{*}{$\begin{array}{c}\text { Najczęściej czytam } \\
\text { literaturę }\end{array}$} & \multirow{2}{*}{\multicolumn{2}{|c|}{$\begin{array}{c}\text { Wszyscy } \\
\mathrm{N}=74\end{array}$}} & \multicolumn{4}{|c|}{ Wskazania ze względu na płeć } \\
\hline & & & \multicolumn{2}{|c|}{$\begin{array}{c}\mathbf{K} \\
\mathrm{N}=49\end{array}$} & \multicolumn{2}{|c|}{$\begin{array}{c}\mathbf{M} \\
\mathrm{N}=25\end{array}$} \\
\hline & Liczba & $\%$ & Liczba & $\%$ & Liczba & $\%$ \\
\hline Obyczajowa & 34 & 45,95 & 31 & 63,27 & 3 & 12,00 \\
\hline Fantastyczną & 29 & 39,19 & 15 & 30,61 & 14 & 56,00 \\
\hline Kryminalna/sensacyjną & 43 & 58,11 & 31 & 63,27 & 12 & 48,00 \\
\hline Przygodowa/podróżniczą & 30 & 40,54 & 18 & 36,73 & 12 & 48,00 \\
\hline Historyczną & 9 & 12,16 & 5 & 10,20 & 4 & 16,00 \\
\hline
\end{tabular}


Tab. 9. c.d. Preferencje czytelnicze respondentów (N=74)

\begin{tabular}{|c|c|c|c|c|c|c|}
\hline \multirow{3}{*}{$\begin{array}{c}\text { Najczęściej czytam } \\
\text { literaturę }\end{array}$} & \multirow{2}{*}{\multicolumn{2}{|c|}{$\begin{array}{l}\text { Wszyscy } \\
\mathrm{N}=74\end{array}$}} & \multicolumn{4}{|c|}{ Wskazania ze względu na płeć } \\
\hline & & & \multicolumn{2}{|c|}{$\begin{array}{c}\mathbf{K} \\
\mathrm{N}=49\end{array}$} & \multicolumn{2}{|c|}{$\begin{array}{c}\mathbf{M} \\
\mathrm{N}=25\end{array}$} \\
\hline & Liczba & $\%$ & Liczba & $\%$ & Liczba & $\%$ \\
\hline Biograficzna/literaturę faktu & 17 & 22,97 & 13 & 26,53 & 4 & 16,00 \\
\hline Komiksy & 11 & 14,86 & 5 & 10,20 & 6 & 24,00 \\
\hline Poezję & 7 & 9,46 & 7 & 14,29 & 0 & - \\
\hline Hobbystyczna/poradniki & 19 & 25,66 & 12 & 24,49 & 7 & 28,00 \\
\hline Popularnonaukowa/naukowa & 12 & 16,22 & 8 & 16,32 & 4 & 16,00 \\
\hline Inną, w tym: & 9 & 12,16 & 7 & 14,29 & 2 & 8,00 \\
\hline religijną & 1 & & 1 & 2,00 & 0 & - \\
\hline romanse & 5 & & 4 & 8,16 & 1 & 4,00 \\
\hline horrory & 3 & & 2 & 4,10 & 1 & 4,00 \\
\hline
\end{tabular}

Źródło: oprac. własne

W celu poznania upodobań czytelniczych, jak również przekonania się o tym, co młodzież szczególnie ceni w książkach, które czyta, poproszono o wskazanie dzieła, będącego według respondentów pozycją obowiązkową, którą należy/trzeba znać (biorąc po uwagę dowolne, przyjęte przez nich, kryteria) i która poleciliby innym. $\mathrm{Na}$ to pytanie odpowiedziało 48 osób (w tym 30 dziewcząt, z czego 3 stwierdziły, iż takiej nie ma, więc nie potrafią wskazać; i 18 chłopców, 1 z nich udzielił odpowiedzi „nie wiem”). Podano łącznie 36 tytułów (dziewczęta -30 ; chłopcy $-17^{3}$ ), nie zawsze jednak argumentując swój wybór. I tak: 4 osoby wymieniły pozycję Pan Tadeusz [Adam Mickiewicz], uzasadniając to w następujący sposób: „to epopeja narodowa”, „takie dzieło trzeba po prostu znać”, ,, nie wiem, jak można aż taki długi tekst napisać właśnie tak - brawo!”, ,jestem pod wrażeniem”. Także 4 osoby wskazały książkę Mały Ksiqże [Antoine de Saint-Exupéry], argumentując, iż: „zawiera w sobie przesłanie”, „jest źródłem cytatów”, „właściwie można ją czytać w każdym wieku”, ,jest piękna”. Po 2 respondentów podało następujące tytuły: Gwiazd naszych wina [John Green] - „świetna książka dla młodzieży”, „strzał w dziesiątkę"; Hopeless [Colleen Hoover] - „oczarowała mnie”; Harry Potter [J. K. Rowling] - „mogę ją czytać i sto razy, nigdy się nie znudzi”, „Harry spowodował, iż nawet polubiłem czytać”, Zbrodnia $i$ kara [Fiodor Dostojewski] - „zainteresowała mnie”, „niezły temat”; My, dzieci z dworca $Z O O$ [Christiane V. Felscherinow] - „powinno się pisać o prawdziwym życiu”, „wstrząsnęła mną”. Pozostałe tytuły pojawiły się tylko raz: Maybe Someday [Colleen Hoover] - „trafia w mój gust”; Przechytrzyó diabła [Napoleon Hill] - „dziwna, ale ciekawa”; Driady [Adam Mickiewicz] - „klasyka!”; Wesele

\footnotetext{
${ }^{3}$ Niektórzy respondenci podawali więcej niż jeden tytuł.
} 
[Stanisław Wyspiański] - „należy znać”; O psie, który jeźdżit koleja [Roman Pisarski] - „pamiętam ją do dziš”; Gra o tron [George R. R. Martin] - „niesamowita”; Mój maż potwór [Ingrid Falaise] - „nie pozwala o sobie zapomnieć”; Kwiat pustyni [Waris Dirie, Cathleen Miller] - „po prostu trzeba ja przeczytać”; Anaruk, chłopiec ₹ Grenlandii [Czesław Centkiewicz] - „przypomina mi dzieciństwo"; seria Jeżycjada [Małgorzata Musierowicz] - „kocham”; Władca pierścieni [John R. R. Tolkien] - „jest najlepsza”; S₹koła uczuć [Nicholas Sparks] - „piękna, zresztą jak wszystkie książki Sparksa”; Łowcy Atlantydy [Andy McDermott]; Człowiek w poszukiwaniu sensu [Viktor Frankl]; Lolita [Vladimir Nabokov]; Metro 2033 [Dmitrij Głuchowski]; Kamienie na szaniec [Aleksander Kamiński]; Ten obcy [Irena Jurgielewiczowa]; cykl Zwiadowcy, [John Flanagan]; Dotyk [Jus Accardo]; seria Archiwum burzowego swiatta [Brandon Sanderson]; Przęnaczenie bohaterów [Morgan Rice]; Bylismy tgarzami [Emily Lockhart]; Zostań, jeśli kochasz. [Gayle Forman]; Obsydian [Jennifer L. Armentrout]; Rywalki [Kiera Cass]; Makbet [William Szekspir]; Drzwi percepcji. Niebo i piekto [Aldous Huxley]; Lalka [Bolesław Prus].

Niewattpliwie, wskazany zbiór jest bardzo różnorodny, zarówno jeśli chodzi o styl, temat, czy też kategorię, do której należa/mogą zostać przyporządkowane poszczególne tytuły. Podane przez młodzież uzasadnienia nie pozwalają na stwierdzenie, jakie kryteria są dla niej wiodące w kontekście uznawania książki za szczególnie ważna/znacząca/godną polecenia. Pomijając fakt, iż tylko część respondentów rozwinęła swe wypowiedzi, to często występowały one jedynie w postaci hasel, nacechowanych emocjonalnie, mających wyrazić podziw dla danej pozycji, przybierających często formę skróconych rekomendacji, nie wyjaśniających wszakże źródeł takiego pozytywnego odbioru i nastawienia.

Odnosząc się do badań realizowanych wcześniej wśród studentów, którzy także mieli za zadanie wskazanie książki, uznawanej przez nich za wspaniałe dzieło i pozycję obowiązkowa (łącznie podano 82), można stwierdzić, że kilka tytułów się powtarza. W czołówce znalazły się, podobnie jak u młodzieży, pozycje: Mały Ksiaże [Antoine de Saint-Exupéry], z największą liczbą wskazań, a tuż za nim Pan Tadeusz. [Adam Mickiewicz]. Pozostałe to: Wladca pierścieni [John R. R. Tolkien], My, dzieci z dworca ZOO [Christiane V. Felscherinow], Harry Potter [J. K. Rowling], Gra o tron [George R. R. Martin], Lolita [Vladimir Nabokov], Kwiat pustyni [Waris Dirie, Cathleen Miller], Zbrodnia $i$ kara [Fiodor Dostojewski] ${ }^{4}$. Trudno jednak na tej podstawie formułować

\footnotetext{
${ }^{4} \mathrm{~W}$ tym miejscu autorka pozwala sobie przywołać jeszcze jedno odniesienie do badań własnych, realizowanych w roku akademickim 2013/2014 wspólnie z A. Tokaj, dotyczących znaczenia książki w życiu dwóch pokoleń: młodych i seniorów (grupa badawcza liczyła 122 osoby, odpowiednio - 56 i 66), gdzie również w ramach jednego z poruszanych wątków,
} 
jakiekolwiek wnioski. Takowe wymagałyby pogłębionych eksploracji badawczych. Jest to raczej jakiś punkt, na który warto byłoby, w opinii autorki, zwrócić szczególną uwage analizując upodobania oraz idące za nimi oceny wartościujące, dokonywane przez młode osoby, będące na różnych etapach wędrówki edukacyjnej, które odpowiadając na tak zadane pytanie - przywołują zarówno literaturę, mająca już pewną tradycję i raczej ugruntowaną w świadomości społecznej (czy sa przekonani do tego wyboru i stoją za nim naprawdę doceniane walory dzieła, czy też dominuje racja „wypada podać ten tytuł’?), jak również bardzo chętnie wskazuja nowości, których na rynku wydawniczym nie brakuje, a które - jak można mniemać - często pozostaja w gestii ich aktualnych doświadczeń czytelniczych (czy na pewno są to aż tak cenione przez nich pozycje, czy też po prostu zapamiętane ze względu na bieżącą lekturę?).

Badaną młodzież poproszono również o subiektywną ocenę zarówno własnej, jak i ogólnie młodego pokolenia, aktywności czytelniczej. Najwięcej respondentów odpowiedziało, iż czyta przeciętnie (40\%), jedynie 4 osoby wskazały, iż bardzo dużo ( 2 z nich, na pytanie o ilość przeczytanych książek, udzieliły odpowiedzi - kilka w miesiącu, 2 pozostałe - średnio 1 książkę na miesiąc) (tabela 10.).

Tab. 10. Ocena respondentów ich własnej aktywności czytelniczej $(\mathrm{N}=80)$

\begin{tabular}{|l|c|c|c|c|c|c|}
\hline \multirow{2}{*}{ Uważam, że czytam } & \multicolumn{2}{|c|}{ Wszyscy } & \multicolumn{3}{c|}{ Wskazania ze względu na płeć } \\
\cline { 2 - 7 } & & \multicolumn{2}{c|}{ K } & \multicolumn{2}{c|}{ M } \\
\cline { 2 - 7 } & Liczba & $\mathbf{0}$ & Liczba & $\mathbf{\%}$ & Liczba & \% \\
\hline Bardzo dużo & 4 & 5,00 & 2 & 4,00 & 2 & 6,67 \\
\hline Dużo & 15 & 18,75 & 11 & 22,00 & 4 & 13,33 \\
\hline Przeciętnie & 32 & 40,00 & 21 & 42,00 & 11 & 36,67 \\
\hline Mało & 18 & 22,50 & 11 & 22,00 & 7 & 23,33 \\
\hline Bardzo mało & 11 & 13,75 & 5 & 10,00 & 6 & 20,00 \\
\hline
\end{tabular}

Źródło: oprac. własne.

Odnosząc się do stanu czytelnictwa wśród młodych ludzi ponad połowa badanych stwierdziła, iż mogłoby być lepiej (55\%), jedynie co dziesiąty re-

odwołujących się do szczególnie istotnych dla respondentów bohaterów literackich, wśród wymienianych przez młodych w czołówce znalazł się Mały Ksią̇e, wspomniani zostali także: Harry Potter i Zosia z Pana Tadeusza. Pozycja Mały Ksiaże została podana też jako ta, którą warto polecić seniorom („Myślę, że jest to książka, która mogłaby łączyć pokolenia. Bez względu na wiek, świat, bohater wykreowany przez autora przypadnie do gustu każdemu”) (Słupska \& Tokaj, 2014, s. 137-158). 
spondent wyraził zadowolenie $z$ obecnej sytuacji, a więcej niż $1 / 3$ - surowo oceniła aktywność czytelniczą rówieśników (tabela 11.).

Tab. 11. Ocena respondentów aktywności czytelniczej młodego pokolenia $(\mathrm{N}=80)$

\begin{tabular}{|c|c|c|c|c|c|c|}
\hline \multirow{3}{*}{$\begin{array}{c}\text { Jak oceniasz stan } \\
\text { czytelnictwa obecnie? }\end{array}$} & \multirow{2}{*}{\multicolumn{2}{|c|}{ Wszyscy }} & \multicolumn{4}{|c|}{ Wskazania ze względu na płeć } \\
\hline & & & \multicolumn{2}{|c|}{$\mathbf{K}$} & \multicolumn{2}{|c|}{$\mathbf{M}$} \\
\hline & Liczba & $\%$ & Liczba & $\%$ & Liczba & $\%$ \\
\hline $\begin{array}{l}\text { Jest dobrze, młodzi ludzie } \\
\text { chętnie czytają }\end{array}$ & 8 & 10,00 & 6 & 12,00 & 2 & 6,67 \\
\hline $\begin{array}{l}\text { Jest przeciętnie, mogłoby } \\
\text { być lepiej }\end{array}$ & 44 & 55,00 & 26 & 52,00 & 18 & 60,00 \\
\hline $\begin{array}{l}\text { Jest źle, młodzież nie czyta } \\
\text { albo robi to niechętnie }\end{array}$ & 28 & 35,00 & 18 & 36,00 & 10 & 33,33 \\
\hline
\end{tabular}

Źródło: oprac. własne.

Zdecydowana większość respondentów wyraziła przekonanie, iż czytanie przynosi korzyści $(90 \%)$, wymieniając wśród nich głównie: wzbogacanie słownictwa, rozwój wyobraźni, poszerzanie wiedzy, ćwiczenie poprawnego posługiwania się językiem polskim, czyli akcentując przede wszystkim jego funkcje pragmatyczno-poznawcze. Jednak 8 osób (10\%) ujawniło opinię przeciwną (wśród nich było 6 chłopców, czyli w ich grupie 20\% i 2 dziewczęta, odpowiednio $4 \%$ ).

Istotne z pedagogicznego punktu widzenia - w kontekście wspierania dynamiki praktyk czytelniczych - jest również nawiązanie do najbliższego środowiska (rodzina, szkoła, biblioteka), które to, jak podkreślała Helena Radlińska, odpowiada za drogi krążenia książek, ich wędrówkę (Lepalczyk, 1974, s. 36). Większość z respondentów, odnosząc się do tradycji rodzinnych w tym zakresie, deklaruje, iż w dzieciństwie rodzice (opiekunowie) czytali im - 63 osoby (78,75\%), 9 osób nie pamięta (11,25\%), a 8 (czyli 10\%) definitywnie odpowiada, że nie miało to miejsca. Płeć nie różnicuje wyników. Na pytanie, kto w okresie dzieciństwa zachęcał respondentów do czytania, najwięcej wskazań uzyskali rodzice - 57,50\%, w dalszej kolejności: dziadkowie - 31,25\%, nauczyciele $-27,50 \%$, rodzeństwo $-8,75 \%$, bibliotekarze $-6,25 \%$. Natomiast 13 osób (16,25\%) udzieliło odpowiedzi, iż nikt tego nie robił. Odnosząc się z kolei do aktualnej sytuacji, zainteresowanie literatura, przekładające się na codzienną aktywność czytelniczą domowników, deklaruje 62 respondentów $(77,5 \%)$, wskazując wśród tych, którzy dużo czytają głównie rodziców $-57,50 \%$, a także dziadków $-21,25 \%$ i rodzeństwo - 18,75\% (możliwość wyboru więcej niż jednej odpowiedzi). Jednak 18 osób (22,5\%) jednoznacznie stwierdza, że nikt $\mathrm{z}$ najbliższych w jakimkolwiek zakresie nie 
jest zainteresowany literaturą. Sytuacja osób, w rodzinach których książka raczej nie była/nie jest obecna w codzienności, a zatem, jak można mniemać, nie przywiązuje się wagi do praktyk czytelniczych, powinna budzić niepokój, gdyż wówczas nie ma nastawienia na rozwój tych zainteresowań i ukształtowanie określonych nawyków. „Kompetentny rodzic powinien mieć świadomość odpowiedzialności wynikającej z funkcji, jaka pełni” i stanowić m.in. „konstruktywny wzorzec osobowy dla swoich dzieci (...), być sprawnym dydaktykiem (...), dobrym trenerem w zakresie korzystania z dóbr kultury" (Forma, 2017, s. 239). Jego nieprzywiązywanie wagi do obcowania w tekstem (w różnym zakresie, w rozmaitych sytuacjach), albo wręcz demonstrowana postawa negatywna, to często kontynuacja zachowań z wcześniejszych okresów. Trudno oczekiwać, by takim nastawieniem mógł przekonać młodego człowieka do literatury (Słupska, 2016b, s. 240).

\section{Podsumowanie}

L Odnoszac się do pytania zawartego w tytule niniejszego artykułu, można stwierdzić, iż książka - obecna w codzienności współczesnego młodego człowieka - nie zajmuje tam pozycji pierwszoplanowej, będąc raczej umiarkowanie ważna, a dla części (stanowiącej jednak mniejszość) - nieistotna. Wśród badanej młodzieży jest też grupa entuzjastycznie nastawiona do praktyk czytelniczych i aktywna na tym polu, choć trzeba zaznaczyć, iż w różnym zakresie odnoszącym się do czytania swobodnego i czytania szkolnego (respondenci, których zaliczyć można do kategorii „czytelników bezwarunkowych”, czy też „czytelników intensywnych”, z różnym zaangażowaniem czytają lektury szkolne - od regularnego zapoznawania się ze wszystkimi lub prawie wszystkimi pozycjami obowiązującymi w ramach lekcji języka polskiego, przez czytanie fragmentaryczne, po sięganie jedynie do streszczeń). Generalnie, badana młodzież sceptycznie podchodzi do lektur, tłumacząc to głównie nieciekawą fabułą, sprawiającym problemy językiem, jakim są napisane, czy też, biorąc pod uwagę okoliczności zewnętrzne - brakiem czasu. Jak wykazała analiza, respondenci - w ramach swobodnego wyboru - w głównej mierze decydują się na beletrystykę, gdzie w ogólnym rankingu zwyciężyła literatura kryminalna/sensacyjna, ciesząc się także największą popularnością wśród dziewcząt, podczas gdy chłopcy wskazywali częściej na fantastykę. Tytuły: Pan Tadeusz i Mały Ksiaże powtarzały się czterokrotnie jako dzieła polecane innym do obowiązkowego zapoznania się. Łącznie prawie połowa respondentów, którzy udzielili odpowiedzi na to pytanie, podała 36 propozycji, tworząc tym samym bardzo różnorodny katalog. Uczniowie ocenili własną aktywność czytelniczą na poziomie przeciętnym, jednak prawie tyle samo 
stwierdziło, iż czyta mało lub bardzo mało. Odnosząc swą ocenę do intensywności podejmowania praktyk lekturowych młodego pokolenia ogólnie, respondenci zbyt optymistyczni nie byli. Tylko $10 \%$ wyraziło zadowolenie, przyznając, że jest dobrze i młodzież chętnie czyta. Odwołując się do socjalizacji czytelniczej i tradycji spotkań z literaturą w najbliższym środowisku uczniów, generalnie stwierdzili, że rodzice czytali im w dzieciństwie, zachęcając ich również, w większości przypadków, do już samodzielnych kontaktów z książkami. Część respondentów wskazywała także - choć w różnych proporcjach - rolę dziadków, nauczycieli, bibliotekarzy, rodzeństwa. Przeszło $1 / 5$ młodych ludzi dorastała jednak w „nieczytającym” domu, gdzie nie było i nie ma zwyczaju uprawiania indywidualnej praktyki czytelniczej.

Przedstawione analizy wyników badań, traktowane jako ilustracja rozważań na temat książki w życiu młodego człowieka i sygnalizowanie wybranych kwestii, związanych z niezwykle rozbudowanym obszarem poznawczym, stanowia, w zamierzeniu autorki, pewien głos w dyskusji prowadzonej wokół - ważnej i z pedagogicznego, i z ogólnospołecznego punktu widzenia - i cały czas aktualnej problematyki.

\section{Bibliografia}

Brzezińska, Anna I. (2017). Tożsamość u progu dorostości. Wižrunek uczniów szłół ponadgimnazjalnych. Poznań: Wydawnictwo Naukowe Wydziału Nauk Społecznych Uniwersytetu im. Adama Mickiewicza w Poznaniu.

Forma, Paulina (2017). Rodzina wielodzietna jako miejsce kształtowania zainteresowań czytelniczych dzieci. W: K. Segiet, K. Słupska (red.), Ksiażka w życiu człowieka - w poszukiwaniu (u)traconej wartości (s. 229-240). Poznań: Wydawnictwo Naukowe Uniwersytetu im. Adama Mickiewicza w Poznaniu.

Janus-Sitarz, Anna (2016). W poszukiwaniu czytelnika. Diagnozy, inspiracje, rekomendacje. Kraków: Universitas.

Koryś, Izabela i in. (2018). Stan czytelnictwa w Polsce w 2017 roku. Warszawa: Biblioteka Narodowa. Pobrane 27 sierpnia 2018, z: https://www.bn.org.pl/download/document /1529572435.pdf

Kostecki, Janusz (2017). Czytelnictwo w Polsce - trwanie i zmiany. W: A. Żbikowska-Migoń, M. Skalska-Zlat (red.), Encyklopedia ksiażki. T. 1, Eseje, A-J (s. XX-YY). Wrocław: Wydawnictwo Uniwersytetu Wrocławskiego.

Lepalczyk, Irena (1974). Pedagogika biblioteczna Heleny Radlinskiej. Lódź: Lódzkie Towarzystwo Naukowe.

Mazur, Elżbieta (2012). Lektury licealistów. Kanon - badania - wnioski. Zesayty Naukowe Uniwersytetu Rzeszowskiego, Seria Filologiczna, Dydaktyka, 7, (72), 188-204.

Słupska, Kamila (2016a). Czytająca młodzież? - między niechęcią a fascynacją (komunikat z badań). W: A. Rzymełka-Frąckiewicz, T. Wilk (red.), Edukacja, kultura, sżtuka - spoistość a integracja (s. 73-89). Katowice: Wydawnictwo Uniwersytetu Śląskiego. 
Słupska, Kamila (2016b). Rola ksiaż̇i i czasopisma w życiu dziecka - o potrzebie rozbudzania zainteresowań czytelniczych najmłodszego pokolenia. W: M. Cywińska (red.), Rozwijanie umiejetności jezykowych i komunikacyjnych dziecka. Wybrane aspekty (s. 239-257). Poznań: Wydawnictwo Naukowe Uniwersytetu im. Adama Mickiewicza.

Słupska, Kamila \& Tokaj, Astrid (2014). Książka w życiu dwóch pokoleń. Pedagogika Społeczna, 3 (53), 137-158.

W rrost caytelnictwa nastoletnich driewczqat (2018). Pobrane 27 sierpnia 2018, z: https://www.bn.org.pl /aktualności/3489-wzrost-czytelnictwa-nastoletnich-dziewczat.html

Zasacka, Zofia (2013). Nastolatki i ich przyjemności czytania książek. W: M. Antczak, A. Brzuska-Kępa, A. Walczak-Niewiadomska (red.), Kultura czytelnicza dzieci i młodzieży poczatku XXI wieku. Szkice bibliologiczne (s. 95-115). Lódź: Wydawnictwo Uniwersytetu Łódzkiego.

Zasacka, Zofia (2014). Caytelnictwo dzieci i mtodzieży. Warszawa: Instytut Badań Edukacyjnych.

\section{Important or insignificant? The book in the everyday life of young adults (research report)}

ABSTRACT: The results of a nationwide research into reading habits do not instill optimism. It has been found that reading books is not a common cultural standard. This paper attempts at presenting the role of books in the life of the young generation. The author seeks to answer the question whether books constitute an inherent part or merely a tolerated, albeit not necessarily desirable element of everyday life. The analysis is based on the results of an empirical study conducted on a group of young adults aged $18-20$, i.e. at a point in life where they complete secondary education and change or have changed their reading preferences. An emphasis is put on the pedagogic perspective (and the related socialization processes) as well as on the role of the environment, i.e. people in the closest social circle, in the development of young adults' reading habits throughout their lives.

KEYWORDS: young adults, reading habits, motivation for reading 